\title{
Terguride as a New Anti-Hyperprolactinemic Agent: Characterization in Rats and Dogs in Comparison with Bromocriptine
}

\author{
Tatsuo Mizokawa ${ }^{1}$, Tetsuo Akai ${ }^{1}$, Yukie Nakada ${ }^{1}$, Motonori Yamaguchi ${ }^{1, *}$, Hidehiko Nakagawa ${ }^{1}$, \\ Syed Hasan ${ }^{2}$, Klaus-Juergen Rettig ${ }^{2}$ and Helmut Wachtel ${ }^{2}$ \\ ${ }^{I}$ Research Department, Nihon Schering K.K., 2-6-64 Nishimiyahara, Yodogawa-ku, Osaka 532, Japan \\ ${ }^{2}$ Research Laboratories, Schering $A G$, Berlin, Germany
}

Received June 18,1993 Accepted July 20, 1993

\begin{abstract}
Terguride, a derivative of the ergot alkaloid, was characterized as a new anti-hyperprolactinemic agent in rats and dogs in comparison with bromocriptine. Terguride was found to bind selectively to the pituitary dopamine $\mathrm{D}_{2}$-receptors with a high affinity $\left(\mathrm{K}_{\mathrm{d}}=0.39 \mathrm{nM}\right)$. In reserpinized rats, terguride at $0.03 \mathrm{mg} / \mathrm{kg}$, p.o. significantly reduced the serum prolactin (PRL) level. The PRL lowering effect and the effective dose were longer lasting and about 30 times lower than those of bromocriptine, respectively. In rats bearing estrogen-induced pituitary prolactinoma, chronic terguride induced shrinkage of the prolactinoma as well as reduction of the high serum PRL level. In lactating rats, terguride $(1.0 \mathrm{mg} / \mathrm{kg}$, s.c.) reduced milk production in the mammary gland, whereas bromocriptine showed no significant effect up to $10 \mathrm{mg} / \mathrm{kg}$, s.c. Terguride $(10 \mathrm{mg} / \mathbf{k g}, \mathrm{p.o}$.) did not induce any stereotypy and hypermotility in reserpinized rats, while bromocriptine induced both stereotypy and hypermotility significantly at $10 \mathrm{mg} / \mathrm{kg}, \mathrm{p} . \mathrm{o}$. In dogs, terguride, like bromocriptine, reduced the serum PRL level, but did not affect the serum levels of growth hormone and luteinizing hormone. In dogs, bromocriptine induced both emesis and PRL-lowering at almost the same dose, whereas emesis-inducing doses of terguride were about 100 times higher than the PRL-lowering dose. These results suggest that terguride as a dopamine $D_{2}$-agonist is a potent inhibitor of PRL secretion with less neurotropic side effects compared to bromocriptine, and thus a useful drug for the treatment of galactorrhea and hyperprolactinemia including prolactinoma.
\end{abstract}

Keywords: Terguride, Bromocriptine, Anti-hyperprolactinemic agent, Dopamine $\mathrm{D}_{2}$-agonist, Emetic action

Dopamine (DA) $\mathrm{D}_{2}$-agonists, belonging to the family of ergot-derived drugs such as bromocriptine and lisuride, are well known to be useful for the treatment of disorders characterized by hypersecretion of prolactin (PRL), such as galactorrhea and prolactinoma $(1,2)$. Bromocriptine, being the most widely utilized, has been shown not only to reduce the high PRL level in patients bearing prolactinoma and in postpartum women, but also to induce shrinkage of the tumor mass and reduction of lactation. However, such treatment is often associated with neurotropic side effects such as nausea and vomiting, which may be due to the $\mathrm{D}_{2}$-agonistic action on the central dopaminergic systems; and as a result, about $10 \%$ of the patients discontinued the treatment $(3-5)$. Thus, the drug development in this field recently has been directed to the search for a potent anti-hyperprolactinemic drug

\footnotetext{
* To whom correspondence should be addressed.
}

without the unwanted neurotropic side effects.

Terguride, a 9,10-transdihydrogenated derivative of the ergot alkaloid lisuride, has been reported to exhibit both agonistic and antagonistic pharmacological effects at the DA $\mathrm{D}_{2}$-receptors depending upon the location and the state of the receptors $(6-9)$. Like $D_{2}$-agonists, terguride inhibits hypersecretion of PRL in reserpinized rats at low doses, suggesting a potent agonistic action on the pituitary DA $\mathrm{D}_{2}$-receptors (6). On the other hand, unlike $\mathrm{D}_{2^{-}}$ agonists, terguride does not induce stereotypy and hyperlocomotion at high doses in rats (10), suggesting that terguride does not stimulate the postsynaptic $\mathrm{D}_{2}$-receptors in the central dopaminergic systems. Thus, despite of its potent inhibition of PRL secretion, terguride is not expected to induce the neurotropic side effects that have been observed with bromocriptine as a typical agonist of the central $D_{2}$-receptors. In line with these observations, preliminary clinical trials suggest that terguride, being an effec- 
tive inhibitor of PRL secretion with few side effects, might be useful for the treatment of hyperprolactinemia $(11-13)$.

In this study, to evaluate furthermore the clinical usefulness of terguride as a new anti-hyperprolactinemic drug, we examined not only its PRL-lowering effects in rat models of hyperprolactinemia, but also its effects on lactation and estrogen-induced prolactinoma, as well as affinity to the pituitary $\mathrm{D}_{2}$-receptors, in comparison with those of bromocriptine. We also compared effects of terguride with those of bromocriptine upon induction of emesis and secretion of growth hormone $(\mathrm{GH})$ and luteinizing hormone $(\mathrm{LH})$ in relation to their PRL-lowering efficacy in dogs.

\section{MATERIALS AND METHODS}

\section{Animals}

Female rats of the Wistar strain (Clea Japan, Inc., Tokyo) were used for experiments with reserpinized, estrogen-treated or lactating rats. Throughout the experimental period, rats were housed in a vivarium controlled at $22 \pm 2{ }^{\circ} \mathrm{C}$ on a 12 -hr light-dark cycle (light period: 07:00-19:00 hr) with water and food freely available. A colony of individually housed male Beagle dogs (Schering AG, Berlin, Germany) weighing 8 to $18 \mathrm{~kg}$ (mean body weight: $14 \mathrm{~kg}$ ) was used for measurements of serum PRL, $\mathrm{GH}$ and $\mathrm{LH}$ levels and for determination of emetic activity. Experimental procedures such as injections, blood sampling or registration of vomiting were always carried out in the animals' home cages.

\section{Drugs}

The following drugs were purchased from commercial sources: Terguride and estradiol valerate (Schering AG), bromocriptine mesylate (bromocriptine; Sigma, St. Louis, MO, USA), reserpine (Apopron injection; Daiichi Pharmaceutical, Tokyo), oxytocin (Atonin O; Teikoku hormone, Tokyo), spiperone, SCH 23390 and (+)butaclamol (Research Biochemicals, Inc., Natik, MA, USA), sulpiride (Dogmatyl injection; Fujisawa Pharmaceutical, Osaka), $\left[{ }^{3} \mathrm{H}\right]$ terguride (Schering AG), $\left[{ }^{3} \mathrm{H}\right]$ spiperone and $\left[{ }^{3} \mathrm{H}\right] \mathrm{SCH} 23390$ (Amersham, Arlington Heights, IL, USA). For the receptor binding studies, all drugs were dissolved in ethanol and then diluted with appropriate buffers. In the experiment using rats, terguride was dissolved in a drop of $8.5 \%$ phosphoric acid solution and made up to an appropriate volume with saline. Bromocriptine was suspended in saline containing $0.5 \%$ sodium carboxymethylcellulose $(\mathrm{W} / \mathrm{W})$ and $0.04 \%$ Tween $80(\mathrm{~W} / \mathrm{W})$ for oral administration and in saline containing $0.1 \%$ tartaric acid for subcutaneous administration. In the experiment using dogs, terguride and bromocriptine were dissolved in saline containing $0.085 \%$ Myrj 53 (W/W). Estradiol valerate (EV) was dissolved in a mixture of sesame oil and benzyl benzoate (ratio of 4 to $1, \mathrm{~V} / \mathrm{V}$ ). Reserpine and oxytocin, commercial preparations for injections, were used. Routes of administration were mainly p.o. in rats and only s.c. in dogs.

\section{Reserpine-induced hyperprolactinemia in rats}

Female Wistar rats weighing $175-200 \mathrm{~g}$ were used. The estrous cycle stage was selected randomly. At $24 \mathrm{hr}$ after reserpine treatment $(2 \mathrm{mg} / \mathrm{kg}$, i.p.), rats were orally administered terguride $(0.003,0.03$ and $0.3 \mathrm{mg} / \mathrm{kg})$ or bromocriptine $(0.1,1.0$ and $10 \mathrm{mg} / \mathrm{kg})$ at a volume of 4 $\mathrm{ml} / \mathrm{kg}$ body weight ( $\mathrm{n}=8$ for each treatment group). Control animals received orally the corresponding volume of saline $(n=16)$. The administration of the test compounds or saline was carried out between 9:00 and 9:15 hr in the morning, and rats were sacrificed by decapitation and the trunk blood collected at 2 and $8 \mathrm{hr}$ after the administration. Serum obtained from the blood sample was stored frozen at $-80^{\circ} \mathrm{C}$ until determination of the PRL level.

\section{EV-induced pituitary prolactinoma in rats}

Female Wistar rats (body weight: $180-220 \mathrm{~g}$ ) received subcutaneously EV $(0.5 \mathrm{mg} / 0.2 \mathrm{ml} / \mathrm{rat})$ once a week for 14 weeks to produce pituitary prolactinoma, according to the method of Dall'Ara et al. (13). Ten days after the final administration of $\mathrm{EV}$, the rats were used for the following experiments. Terguride $(0.3$ or $1.0 \mathrm{mg} / \mathrm{kg}$ ) or saline was orally administered at a volume of $3 \mathrm{ml} / \mathrm{kg}$, once a day for 4 weeks ( $n=14-15$ for each treatment group). On the day after the final administration, the rats were sacrificed by decapitation under anesthesia with ether; then the trunk blood was collected, and the wet weight of the isolated pituitary was measured. Serum obtained from the blood sample was stored frozen at $-80^{\circ} \mathrm{C}$ until the PRL determination. The pituitary was fixed in formal-sublimate ( 1 part formalin +9 parts of saturated aqueous solution of $\mathrm{HgCl}_{2}$ ) for histological analysis. Paraffin sections from the pituitaries were stained with carmoisin $\mathrm{L}$, orange $G$, aniline blue and acid alizarin blue to stain specifically PRL, GH, and gonadotropin (14).

Prior to the administration and 2-3 days before the final administration of $1.0 \mathrm{mg} / \mathrm{kg}$ terguride, anesthetized rats with pentobarbital $(30 \mathrm{mg} / \mathrm{kg})$ and urethane $(1 \mathrm{~g} / \mathrm{kg})$ were subjected to $\mathrm{T} 2$-weighted magnetic resonance (MR) imaging to examine the volume change of pituitary prolactinoma, in which a $4.7 \mathrm{~T}$ MR imaging system (Omega CSI-11; General Electric Instrument, Fremont, CA, USA) with a $33-\mathrm{cm}$ bore magnet was used.

\section{Milk volume and $P R L$ level in lactating rats}

Female Wistar rats (body weight: $220-290 \mathrm{~g}$ ) after mat- 
ing with male Wistar rats were delivered of litters of pups. Three days after the delivery, each mother rat was adjusted to have five male and three female pups. Between 11 and 14 days after the delivery, the lactating mother rats received subcutaneously terguride $(0.3,1.0$ and 3.0 $\mathrm{mg} / \mathrm{kg})$ or bromocriptine $(0.1,1.0$ and $10 \mathrm{mg} / \mathrm{kg})$ once a day ( $n=5-7$ for each treatment group). Immediately after the final administration, pups were isolated from the mother rats; and $3 \mathrm{hr}$ later, the mother rats received oxytocin $(0.1 \mathrm{IU} / \mathrm{rat}$, s.c. $)$, and then the drops of milk were collected from the nipples of the inguinal mammary gland. Then the mother rats were sacrificed by decapitation under anesthesia with ether and the wet weights of the isolated mammary glands were measured. The drops of milk and the isolated mammary glands were stored at $-20^{\circ} \mathrm{C}$ until measurement. In some of the mother rats, breast mammary glands were removed and fixed in $3 \%$ formalin solution for histological analysis. The paraffin section from the mammary glands were stained with hematoxylin and eosin.

The milk volume in the mammary glands was determined by the method of Nicholas and Hartmann (15). Briefly, the isolated mammary glands were homogenized in $0.1 \mathrm{M}$ potassium phosphate buffer $(\mathrm{pH} \mathrm{7.0)}$ at a volume tenfold the volume of the mammary glands. After centrifugation $(40,000 \times \mathrm{g})$ for $60 \mathrm{~min}$ at $4^{\circ} \mathrm{C}$, the supernatant was collected and used to determine the total amount of lactose in the mammary glands. The lactose concentration in the isolated milk was used as the indicator of milk volume, and milk volume in the mammary gland was calculated by the following equation:

$$
\mathrm{MV}=\mathrm{LC} / \mathrm{ML}
$$

in which $\mathrm{MV}$ is the milk volume in the mammary gland, $\mathrm{LC}$ is the lactose content in the mammary gland, ML is the lactose concentration in milk.

Lactose was hydrolyzed into glucose and galactose by the incubation with $\beta$-galactosidase (Sigma). Glucose before and after hydrolysis of lactose was measured by a glucose measurement kit (Glucose B Test Wako; Wako Pure Chemical Industries, Osaka).

\section{Stereotypy and locomotor activity in rats}

Female Wistar rats weighing $160-180 \mathrm{~g}$ were used. At $24 \mathrm{hr}$ after reserpine treatment $(2 \mathrm{mg} / \mathrm{kg}$, i.p. $)$, rats received orally terguride $(3,10 \mathrm{mg} / \mathrm{kg}$ ) and bromocriptine $(3,10 \mathrm{mg} / \mathrm{kg})$. Control animals received orally the corresponding volume of the vehicle. Stereotypy (sniffing, licking and biting) was observed for $1 \mathrm{~min} / \mathrm{rat}$ at intervals of $30 \mathrm{~min}$ in the 2 -hr period after the administration and thereafter at intervals of $1 \mathrm{hr}$ for a consecutive $5 \mathrm{hr}(16)$. The rating system is as follows: sniffing, $0=$ none, $1=$ discontinuous sniffing, $2=$ continuous sniffing; licking and biting, $0=$ none, $1=$ discontinuous licking, $2=$ discontinu- ous biting, $3=$ continuous biting. Immediately after the administration, the locomotor activities of the rats were measured continuously for $7 \mathrm{hr}$ with a photocell motility meter.

\section{Serum PRL, GH and LH levels in dogs}

Male beagle dogs received subcutaneously terguride $(0.003,0.01$ and $0.03 \mathrm{mg} / \mathrm{kg})$ and bromocriptine $(0.001$, 0.03 and $0.01 \mathrm{mg} / \mathrm{kg}$ ). Various dosages of the test compounds were injected in a volume of $0.5 \mathrm{ml} / \mathrm{kg}$ body weight with randomized allocation of treatments. Control animals received subcutaneously the corresponding volume of the vehicle ( $\mathrm{n}=5$ for each treatment). Immediately prior to and $2 \mathrm{hr}$ after drug or vehicle administration, blood sampling $(5 \mathrm{ml})$ was carried out through the jugular vein. Sera obtained from the blood samples were stored frozen at $-80^{\circ} \mathrm{C}$ until determination of hormones.

\section{Emetic action in dogs}

Male beagle dogs described above were used. After fasting for $24 \mathrm{hr}$, the dogs received a measured amount of standard diet on the experimental day prior to subcutaneous treatment with the test compounds or the vehicle. Terguride was tested at dosages of $0.03,0.1,0.3,1.0,1.5$, $2.0,2.5,3.0 \mathrm{mg} / \mathrm{kg}$, s.c.; and bromocriptine was tested at dosages of $0.003,0.008,0.01,0.0125,0.014,0.02,0.03$ $\mathrm{mg} / \mathrm{kg}$, s.c. The various dosages of drugs were administered subcutaneously in a volume of $0.5 \mathrm{ml} / \mathrm{kg}$ body weight with randomized allocation of treatments. Control animals received the corresponding volume of the vehicle $(\mathrm{n}=5$ for each treatment group). Immediately after the injection, individual dogs were observed in their home cages for the presence and frequency of vomiting during a period of $2 \mathrm{hr}$ by an experienced technician who was unaware of the treatment. The number of dogs exhibiting vomiting per treatment group was determined, and the effective doses $\left(\mathrm{ED}_{50}\right)$ were calculated.

\section{Receptor binding studies}

Male Wistar rats were used. Rats were decapitated, and the brain and pituitary were rapidly removed. Striatal and pituitary membrane fractions were prepared as previously described (17) and suspended in the TEAP buffer, which contained $15 \mathrm{mM}$ Tris $\mathrm{HCl}$ (pH 7.4), 5 mM EDTA, 1.1 $\mathrm{mM}$ ascorbic acid, and $12.5 \mu \mathrm{M}$ pargyline, and TNP buffer, which contained $50 \mathrm{mM}$ Tris $\mathrm{HCl}(\mathrm{pH} 7.7), 120$ $\mathrm{mM} \mathrm{NaCl}, 5 \mathrm{mM} \mathrm{KCl}, 2 \mathrm{mM} \mathrm{CaCl}, 1 \mathrm{mM} \mathrm{MgCl}_{2}, 10 \mu \mathrm{M}$ pargyline, and $0.1 \%(\mathrm{~W} / \mathrm{V})$ ascorbic acid. The protein content was determined by the method of Lowry et al. (18).

Inhibitory effects of terguride or bromocriptine on the binding of $\left[{ }^{3} \mathrm{H}\right]$ spiperone and $\left[{ }^{3} \mathrm{H}\right] \mathrm{SCH} 23390$ in striatal and pituitary membranes were determined by incubating 
$\left[{ }^{3} \mathrm{H}\right] \mathrm{ligand}$ and membrane preparations (100 $\mu \mathrm{g}$ protein/tube) at $37^{\circ} \mathrm{C}$ for $30 \mathrm{~min}$ in the presence of various concentrations of terguride or bromocriptine $(0.1-1000$ $\mathrm{nM}$ for the striatal preparation and $1-1000 \mathrm{nM}$ for the pituitary preparation). The samples were filtered under vacuum through Whatman GF/B filters followed by three washes with cold $5 \mathrm{ml}$ TEAP or TNP buffer. Radioactivity was measured by a liquid scintillation counter. Nonspecific bindings of $D_{1^{-}}$and $D_{2}$-ligands for the striatal preparation were determined in the presence of $1 \mu \mathrm{M}$ $\mathrm{SCH} 23390$ and $1 \mu \mathrm{M}(+)$-butaclamol, respectively. Nonspecific binding of $\mathrm{D}_{2}$-ligand for pituitary preparation was determined in the presence of $10 \mu \mathrm{M}$ sulpiride. Binding of $\left[{ }^{3} \mathrm{H}\right]$ terguride and $\left[{ }^{3} \mathrm{H}\right]$ spiperone to pituitary membranes was determined by the method of Rovescalli et al. (19). Briefly, various concentrations of $\left[{ }^{3} \mathrm{H}\right]$ terguride $(0.25-2.0 \mathrm{nM})$ or $\left[{ }^{3} \mathrm{H}\right]$ spiperone $(0.0125-0.2 \mathrm{nM})$ were incubated with the pituitary membrane preparation (100$200 \mu \mathrm{g}$ protein/tube) at $37^{\circ} \mathrm{C}$ for $30 \mathrm{~min}$, and then the samples were treated as described above. Nonspecific binding was determined in the presence of $10 \mu \mathrm{M}$ sulpiride.

\section{Hormone assay}

Determination of serum PRL, GH and LH were carried out by the method of radioimmunoassay (RIA). RIA reagents for rat PRL, dog PRL, GH and LH were kindly supplied by NIAMDD (Baltimore, MD, USA). The method of RIA for dog PRL (20), GH (21) and LH (22) were previously described. Their levels were expressed as $\mathrm{ng} / \mathrm{ml}$ of serum. Rat PRL level was measured by doubleantibody RIA, and the PRL level was expressed as $\mathrm{ng} / \mathrm{ml}$ of serum, using PRL RP-2 as standards. The $\mathrm{ED}_{50}$ for the rat $P R L$ assay was $470 \mathrm{ng}$, and the limit of sensitivity was $25 \mathrm{pg} /$ tube. The intra-assay coefficients of variation were below $10 \%$ for each assay. The inter-assay coefficients of variation were $15 \%$. All samples from a single experiment were analyzed in the same assay to control inter-assay variation.

\section{Statistical analyses}

Experimental data from the PRL-lowering tests in dogs were subjected to analysis of variance in conjunction with the Dunnett's test, and the data from all the other experiments were analyzed by the Kruskal-Wallis test in conjunction with the Scheffe's test. Statistical significance was defined as more than $95 \%$ of probability. $\mathrm{ED}_{50}$ doses ( $95 \%$ confidence limits) for emetic action was calculated by means of probit analysis.

\section{RESULTS}

\section{Receptor binding studies}

In displacement of $\left[{ }^{3} \mathrm{H}\right]$ spiperone and $\left[{ }^{3} \mathrm{H}\right] \mathrm{SCH} 23390$ bindings to the rat striatal membrane, terguride, like bromocriptine, was found to bind with a higher affinity to the $\mathrm{D}_{2}$-receptors than to the $\mathrm{D}_{1}$-receptors (Table $\mathbf{l}(\mathrm{A})$ ). Furthermore, terguride was found to bind with a higher affinity to the pituitary $\mathrm{D}_{2}$-receptors $\left(\mathrm{K}_{\mathrm{i}}=0.9 \mathrm{nM}\right)$ than to the striatal $\mathrm{D}_{2}$-receptors $\left(\mathrm{K}_{\mathrm{i}}=3.5 \mathrm{nM}\right)$, and the affinity was about 2 times higher than that of bromocriptine.

Specific binding of $\left[{ }^{3} \mathrm{H}\right]$ terguride to dopamine $\mathrm{D}_{2}$-receptors was found in the membrane homogenate of the rat anterior pituitary (Table $1(B)$ ). The affinity of $\left[{ }^{3} \mathrm{H}\right]$ terguride to the $\mathrm{D}_{2}$-receptors was high $\left(\mathrm{K}_{\mathrm{d}}=0.39 \mathrm{nM}\right)$ and was similar to that estimated from the displacement of $\left[{ }^{3} \mathrm{H}\right]$ spiperone binding described above. The maximal amount of the binding of $\left[{ }^{3} \mathrm{H}\right]$ terguride $(58 \mathrm{fmol} / \mathrm{mg}$ protein) was almost the same as that of $\left[{ }^{3} \mathrm{H}\right]$ spiperone $(45 \mathrm{fmol} / \mathrm{mg}$ protein).

\section{Effects on reserpine-induced hyperprolactinemia in rats}

In reserpinized female rats, terguride, like bromocriptine, reduced the serum PRL level in a dose-dependent manner at $2 \mathrm{hr}$ after the administration. Significant reduction of the PRL level was observed at 0.03 and $0.3 \mathrm{mg} / \mathrm{kg}$ of terguride or 1.0 and $10 \mathrm{mg} / \mathrm{kg}$ of bromocriptine (see the upper figure in Fig. 1). The effective dose of terguride was about 30 times lower than that of bromocriptine. The PRL-lowering action of terguride remained $8 \mathrm{hr}$ after the administration, but that of bromocriptine almost disappeared (see the lower figure in Fig. 1).

Table 1. Bindings of terguride and bromocriptine to rat striatal and pituitary dopamine receptors

(A) Affinity of terguride and bromocriptine to the dopamine $\mathrm{D}_{1}$ - and $\mathrm{D}_{2}$-receptors

\begin{tabular}{|c|c|c|c|c|}
\hline \multirow{2}{*}{ Test compound } & & \multicolumn{2}{|c|}{ Striatum } & \multirow{2}{*}{$\begin{array}{c}\text { Pituitary } \\
\mathrm{D}_{2}\end{array}$} \\
\hline & & $\mathrm{D}_{1}$ & $\mathrm{D}_{2}$ & \\
\hline Terguride & $\mathrm{K}_{\mathrm{i}}(\mathrm{nM})$ & 87 & 3.5 & 0.9 \\
\hline Bromocriptine & $\mathrm{K}_{\mathrm{i}}(\mathrm{nM})$ & 583 & 8.5 & 1.7 \\
\hline
\end{tabular}

(B) Bindings of $\left[{ }^{3} \mathrm{H}\right]$ terguride and $\left[{ }^{3} \mathrm{H}\right]$ spiperone to the pituitary $\mathrm{D}_{2}$-receptors

\begin{tabular}{lcc}
\hline \multirow{2}{*}{ Radioligands } & \multicolumn{2}{c}{$\mathrm{D}_{2}$-receptor binding } \\
& $\mathrm{K}_{\mathrm{d}}(\mathrm{nM})$ & $\mathrm{B}_{\max }(\mathrm{fmol} / \mathrm{mg})$ \\
\hline$\left[{ }^{3} \mathrm{H}\right]$ Terguride & $0.39 \pm 0.05$ & $58 \pm 8$ \\
{$\left[{ }^{3} \mathrm{H}\right]$ Spiperone } & $0.06 \pm 0.01$ & $45 \pm 4$ \\
\hline
\end{tabular}

The in vitro binding experiments were carried out in membrane preparations of the striatum and the anterior pituitary of rats. (A): $\left[{ }^{3} \mathrm{H}\right] \mathrm{SCH} 23390$ and $\left[{ }^{3} \mathrm{H}\right]$ spiperone were used as ligands for dopamine $D_{1}$ - and $D_{2}$-receptors, respectively. $(B)$ : The $K_{d}$ and $B_{\max }$ values were calculated from Scatchard analysis of the specific $\left[{ }^{3} \mathrm{H}\right]$ terguride or $\left[{ }^{3} \mathrm{H}\right]$ spiperone binding. Values represent the mean \pm S.E.M. of triplicate determinations. 

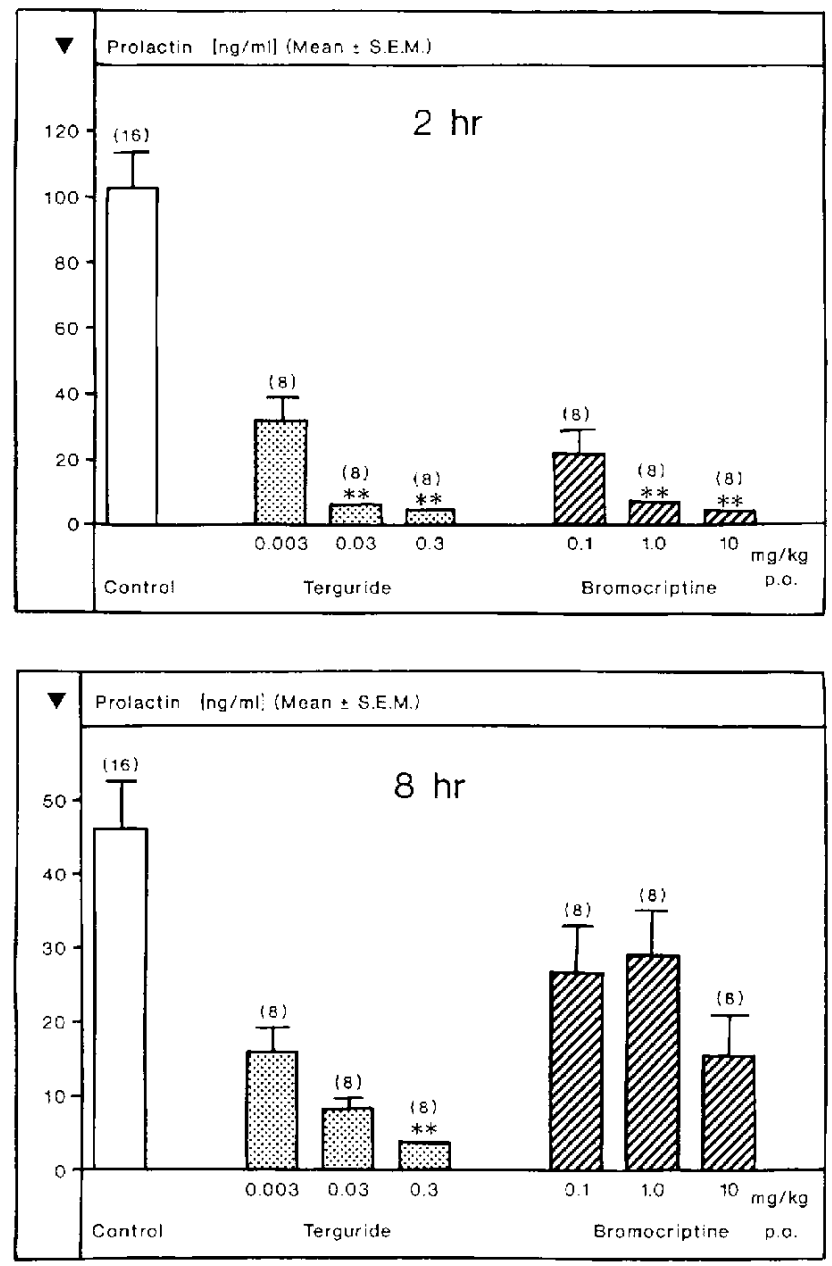

Fig. 1. Effects of terguride and bromocriptine on hyperprolactinemia in reserpine-treated rats. At $24 \mathrm{hr}$ after treatment of female rats with reserpine $(2 \mathrm{mg} / \mathrm{kg}$, i.p.), terguride and bromocriptine were administered orally. Serum prolactin levels were measured 2 and 8 hr after the treatment. Values are the mean \pm S.E.M.; significantly different from the vehicle control (Kruskal-Wallis test in conjunction with Scheffe's test): ${ }^{* *} \mathrm{P}<0.01$. ( ): number of animals tested.

\section{Effects on estrogen-induced pituitary prolactinoma in rats}

The intermittent administration of EV gradually increased not only the serum PRL concentration to reach the value of $1100 \mathrm{ng} / \mathrm{ml}$ after the 14th injection, but also markedly increased the weight of the pituitary to reach the value of $75 \mathrm{mg}$, which was about fivefold greater than those of the pituitaries before the treatment (Fig. 2). The $\mathrm{T} 2$ weighted MR images of the EV-treated rats, taken at one week after the last EV injection, indicated a large area of hyperintense signals in the pituitary-hypothalamic brain region (see the arrow in Fig. 3). The enlarged pituitary tissues were found to be rich in hypertrophic PRLsecreting cells with enlarged vacuoles and PRL-containing vesicles which were stained red (see the cells with arrow in Fig. 4). In rats bearing the EV-induced prolac-

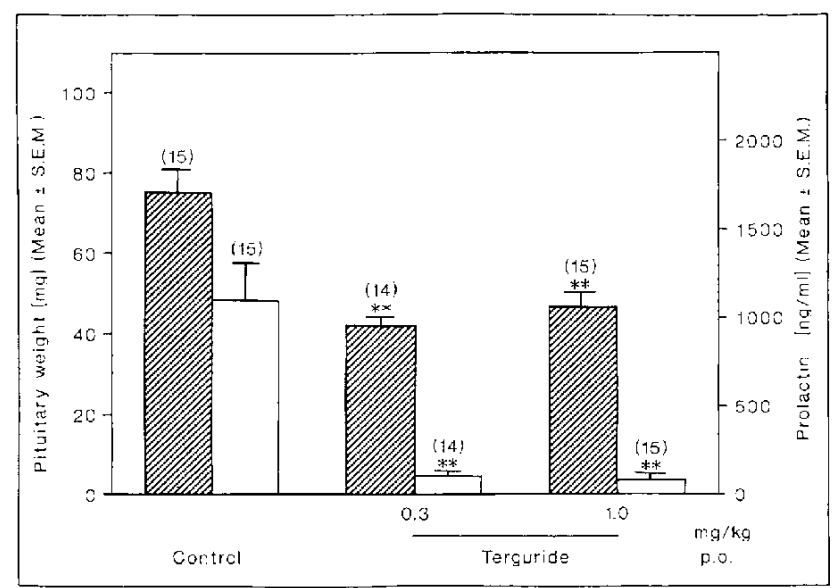

Fig. 2. Effects of terguride on estrogen-induced pituitary prolactinoma in rats. The pituitary prolactinoma was induced by chronic estrogen treatment (for details, see the Methods). At 10 days after the final estrogen treatment, terguride or saline was administered orally once a day for 4 weeks. Values are the mean \pm S.E.M.; significantly different from the vehicle control (Kruskal-Wallis test in conjunction with Scheffe's test): ${ }^{* *} \mathbf{P}<0.01$. ( ): number of animals tested. Pituitary weight, $\square$ : Prolactin level.

tinoma, terguride $(0.3$ and $1.0 \mathrm{mg} / \mathrm{kg})$ induced a marked reduction of the high serum $P R L$ levels to reach values of approximately $100 \mathrm{ng} / \mathrm{ml}$ one day after the start of the oral administration (data not shown), which lasted during the 4 weeks repeated administration. The repeated administration of terguride not only induced a significant decrease in the wet weight of the pituitary prolactinomas (Fig. 2), but also reduced the size (see the MR imaging in Fig. 3), which was accompanied by disappearance of the enlarged vacuoles and, as a result, shrinkage in the hypertrophic PRL-secreting cells (Fig. 4).

Effects on milk volume and PRL levels in lactating rats

Terguride dose-dependently induced a significant reduction of the milk volume in the mammary glands of lactating rats (Fig. 5), as well as a significant reduction of the serum PRL level (data not shown). Terguride also induced shrinkage of the alveoli of the mammary glands in lactating rats (Fig. 6). Bromocriptine showed a tendency to reduce the milk volume in the mammary glands, but no statistical significance was obtained even at $10 \mathrm{mg} / \mathrm{kg}$, s.c. (Fig. 5).

\section{Effects on stereotypy and locomotor activity in reserpin-} ized rats

Terguride did not show any induction of stereotypy and hypermotility up to $10 \mathrm{mg} / \mathrm{kg}, \mathrm{p} . \mathrm{o}$. in reserpinized female rats, while bromocriptine induced both stereotypy and hypermotility significantly at $10 \mathrm{mg} / \mathrm{kg}$, p.o. (Table 2). 

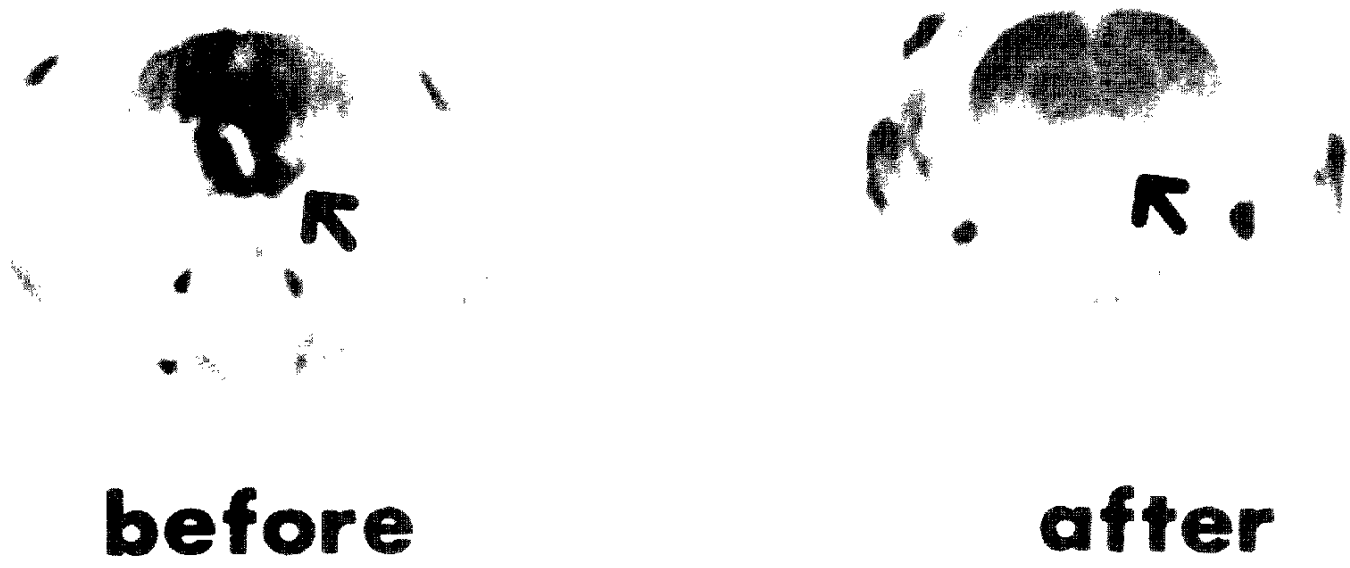

\section{after}

\section{treatment with terguride ( $1 \mathrm{mg} / \mathrm{kg})$}

Fig. 3. MR imaging of estrogen-induced pituitary prolactinoma in rat brain before and after treatment with terguride. For details of the induction of prolactinoma and treatment of teruguride, see the Methods. Prior to the administration of terguride and 2-3 days before the final administration of terguride, the same rats were subjected to T2-weighted MR images. The white arrow indicates the position of the pituitary prolactinoma.
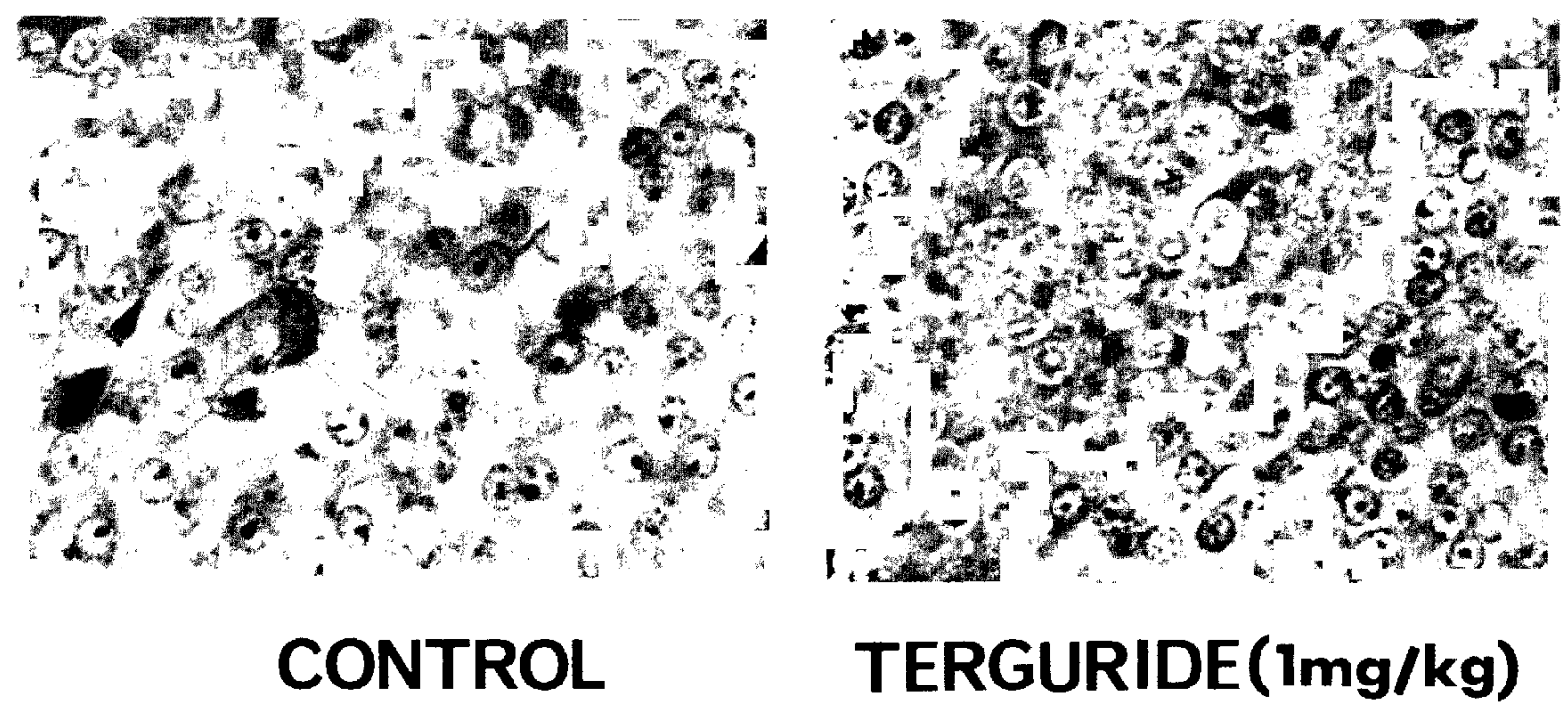

Fig. 4. Light photomicrography of the estrogen-induced pituitary rat prolactinoma after treatment with terguride or saline. The control pituitaries revealed a majority of the cells exhibiting hypertrophy with PRL-containing vesicles which were stained red (see the arrow). In the pituitaries treated with terguride, most cells were shrunken and compacted in contrast to those of the control pituitaries. The methods for staining were described in the Methods. $\times 400$. 


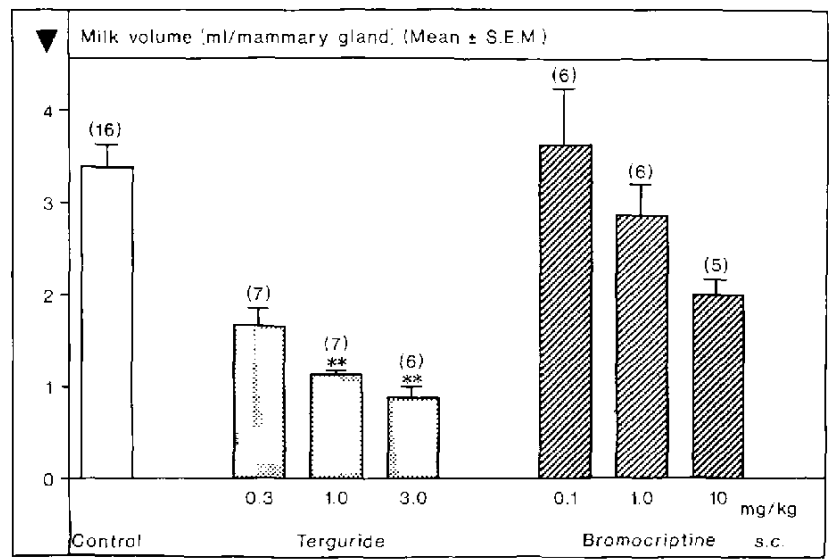

Fig. 5. Effects of terguride and bromocriptine on milk volume in lactating rats. Mother rats received terguride or bromocriptine once a day between 11 and 14 days after the delivery. At $3 \mathrm{hr}$ after the final administration, the mother rats were sacrificed to determined the milk volume in the mammary gland as described in the Methods. Values are the mean \pm S.E.M.; significantly different from the vehicle control (Kruskal-Wallis test in conjunction with Scheffe's test): ${ }^{* *} \mathrm{P}<0.01$. ( ): number of animal tested.

\section{Effects on serum PRL, GH and LH levels in dogs}

Terguride significantly reduced the serum PRL level at $0.01 \mathrm{mg} / \mathrm{kg}$ in male beagle dogs, which was similar to bromocriptine, showing significant decreases at 0.01 and $0.03 \mathrm{mg} / \mathrm{kg}$, s.c. (Fig. 7). On the other hand, both terguride and bromocriptine did not affect serum GH and LH levels at the doses tested (Table 3).
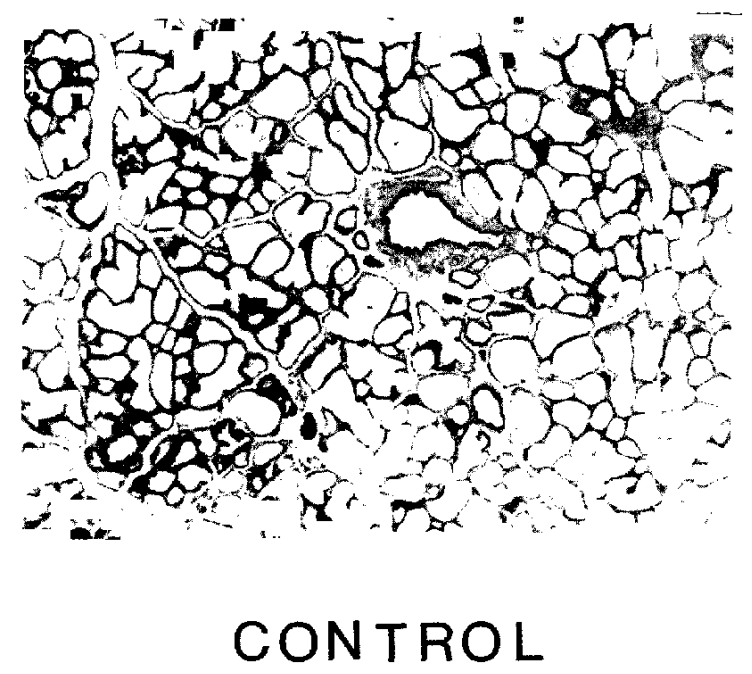

Table 2. Effect of terguride and bromocriptine on stereotyped behavior and locomotor activity in reserpinized rats

\begin{tabular}{lcccc}
\hline Treatment & $\begin{array}{c}\text { Dose } \\
\text { (mg/kg, p.o.) }\end{array}$ & $\mathrm{n}$ & $\begin{array}{c}\text { Stereotyped } \\
\text { behavior } \\
\text { (total score) }\end{array}$ & $\begin{array}{c}\text { Locomotor } \\
\text { activity } \\
\text { (total counts) }\end{array}$ \\
\hline Control & - & 10 & $0^{1)}$ & $556 \pm 526$ \\
Terguride & 3 & 10 & $0.2 \pm 0.4$ & $786 \pm 373$ \\
& 10 & 10 & $0^{1)}$ & $697 \pm 683$ \\
\hline Control & - & 19 & $0.1 \pm 0.5^{7)}$ & $373 \pm 149$ \\
Bromocriptine & 3 & 9 & 0 & $452 \pm 259^{3)}$ \\
& 10 & 10 & $3.6 \pm 3.4^{* *}$ & $2462 \pm 1446^{* *}$ \\
\hline
\end{tabular}

At $24 \mathrm{hr}$ after reserpine treatment $(2 \mathrm{mg} / \mathrm{kg}$, i.p.), female Wistar rats were treated p.o. with various doses of the test compounds or with the vehicle. Stereotypies and locomotor activity were measured during the $7-\mathrm{hr}$ period after treatment. Values represent the mean \pm S.E.M. ${ }^{* *} \mathrm{P}<0.05$ vs. control group (Kruskal-Wallis test in conjunction with Scheffe's test). ${ }^{1)} n=9,{ }^{21} n=18,{ }^{3)} n=8$.

\section{Effects on emesis in dogs}

Terguride, like bromocriptine, induced vomiting in beagle dogs in a dose-dependent manner, but the effective dose was about 70 - to 80 -fold higher than that of bromocriptine (Table 4). On the other hand, both terguride and bromocriptine induced PRL-lowering effects at $0.01 \mathrm{mg} / \mathrm{kg}$, s.c. in beagle dogs as described above (Table 4). As a result, the effective dose of terguride for the vomiting was about 100 -fold higher than that for the PRL-lowering, whereas the effective dose of bromocrip-

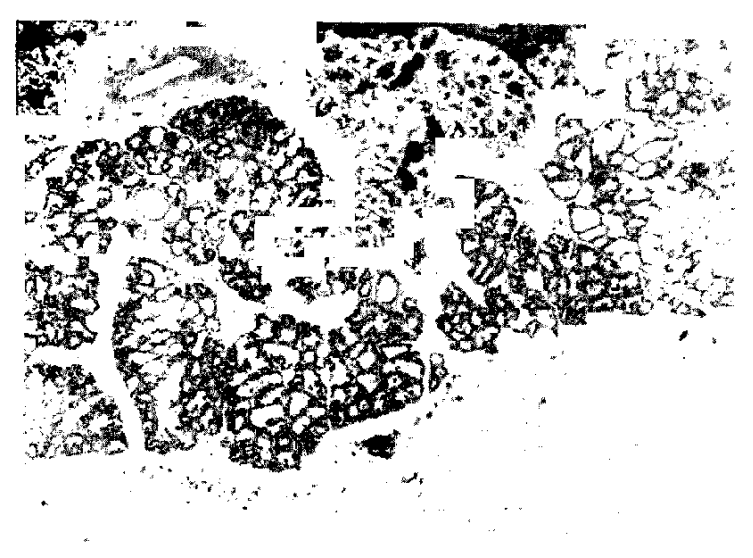

\section{TERGURIDE (3 $\mathbf{m g} / \mathbf{k g})$}

Fig. 6. Mammary gland in lactating rats after treatment with terguride. The mother rats received terguride or saline once a day between 11 and 14 days after the delivery. At $3 \mathrm{hr}$ after the final administration, the mother rats were sacrificed to isolate the mammary glands, which were then stained with haematoxylin and eosin, $\times 10$. 


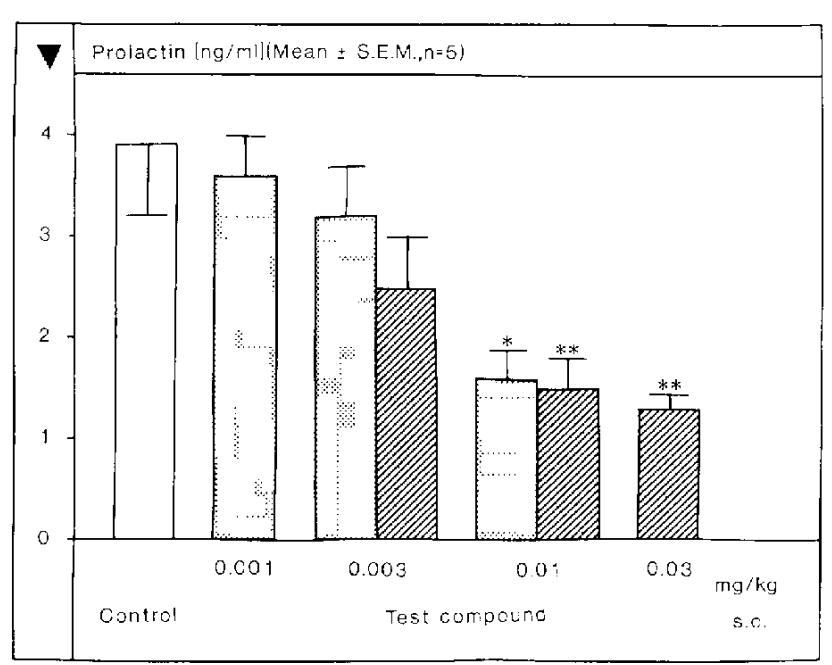

Fig. 7. Effects of terguride and bromocriptine on serum prolactin level in dogs. Male beagle dogs were treated s.c. with various doses of the test compounds or with the vehicle. Serum prolactin levels were measured at $2 \mathrm{hr}$ after s.c. treatment. Values are the mean \pm S.E.M.; significantly different from the vehicle control (analysis of variance in conjunction with Dunnett's test): ${ }^{*} \mathrm{P}<0.05$, ${ }^{* *} \mathrm{P}<0.01$. . B Bromocriptine, $\mathbb{Z}$ : Terguride.

Table 3. Effect of terguride and bromocriptine on serum level of growth hormone (A) and luteinizing hormone (B) in dogs

(A) Serum growth hormone $(\mathrm{ng} / \mathrm{ml})$

\begin{tabular}{lccccc}
\hline \multirow{2}{*}{ Test compound } & \multicolumn{4}{c}{ Vehicle of test compound (mg/kg, s.c.) } \\
\cline { 3 - 6 } & & 0.001 & 0.003 & 0.01 & 0.03 \\
\hline Terguride & $5.2 \pm 0.3$ & - & $6.0 \pm 0.6$ & $4.8 \pm 0.4$ & $4.5 \pm 0.3$ \\
Bromocriptine & $5.2 \pm 0.3$ & $5.2 \pm 0.6^{1)}$ & $5.7 \pm 1.0$ & $6.3 \pm 1.2$ & -
\end{tabular}

(B) Serum luteinizing hormone $(\mathrm{ng} / \mathrm{ml})$

\begin{tabular}{lccccc}
\hline \multirow{2}{*}{ Test compound } & Vehicle & \multicolumn{4}{c}{ Dose of test compound (mg/kg, s.c.) } \\
\cline { 3 - 6 } & 0.001 & 0.003 & 0.01 & 0.03 \\
\hline Terguride & $4.7 \pm 1.6^{1)}$ & - & $4.7 \pm 0.9$ & $3.7 \pm 1.4$ & $5.7 \pm 1.5^{1)}$ \\
Bromocriptine & $4.7 \pm 1.6^{1)}$ & $3.2 \pm 0.8^{1)}$ & $3.0 \pm 0.5$ & $2.8 \pm 0.5^{1)}$ & - \\
\hline
\end{tabular}

Hormone levels were determined at $2 \mathrm{hr}$ after s.c. injection of test compounds or vehicle. Values represent the mean \pm S.E.M. of 4 to 5 animals per group. - : not tested, ${ }^{1)}: \mathrm{n}=4$.

tine for the vomiting was almost the same as that for the PRL-lowering.

\section{DISCUSSION}

Ergot derivatives such as bromocriptine and lisuride are well known to reduce serum PRL levels in humans as well as animals $(23,24)$. Inhibition of PRL secretion from
Table 4. Prolactin lowering efficacy of terguride and bromocriptine in relation to their emetic action in dogs

\begin{tabular}{lcc}
\hline Test compound & $\begin{array}{c}\text { Inhibition of PRL secretion } \\
\text { MED (mg/kg, s.c.) }\end{array}$ & $\begin{array}{c}\text { Emetic action } \\
\mathrm{ED}_{50}(\mathrm{mg} / \mathrm{kg}, \mathrm{s.c.})\end{array}$ \\
\hline Terguride & 0.01 & $0.99(0.41-1.53)$ \\
Bromocriptine & 0.01 & $0.013(0.011-0.017)$ \\
\hline
\end{tabular}

Serum prolactin levels were measured $2 \mathrm{hr}$ after treatment (cf. legend of Fig. 7). The number of animals per treatment group $(n=5)$ exhibiting emesis for $2 \mathrm{hr}$ following treatment was observed, and the effective doses were calculated by means of probit analysis. MED: minimal effective dose.

the PRL-producing cells of the anterior pituitary is thought to be mediated through their direct agonistic action on $\mathrm{D}_{2}$-receptors of the lactotroph cells $(25,26)$. In this study, terguride, like bromocriptine, was found to bind to the anterior pituitary $D_{2}$-receptors with high affinity and to produce a significant lowering of serum PRL levels in reserpinized or lactating rats and in intact male dogs. These results suggest that terguride, like bromocriptine, acts as an agonist at the pituitary $\mathrm{D}_{2}$-receptors and, as a result, reduces serum PRL levels in hyperprolactinemic animals. Furthermore, terguride induced shrinkage of the hypertrophic lactotroph, and this resulted in the reduction of EV-induced prolactinomas in rats, which is consistent with previous findings with bromocriptine $(27,28)$. Finally, in addition to reducing the serum PRL levels, terguride also reduced the milk volume of mammary glands in lactating rats. These results indicate that terguride may be useful for the treatment of prolactinoma and galactorrhea which are accompanied by hypersecretion of PRL.

Both emesis in dogs and stereotypy or hypermotility in rats have been considered as indicators for $D_{2}$-agonistic action on the central dopaminergic system. In this study, bromocriptine induced both emetic and PRL-lowering effects at almost the same doses, while the emesis-inducing dose of terguride in dogs was about 100 times higher than that for the PRL-lowering effect. Terguride did not induce any stereotypy and locomotor stimulation up to $10 \mathrm{mg} / \mathrm{kg}$, p.o. in reserpinized female rats, which is consistent with previous results in male rats. In contrast, bromocriptine induced both stereotypy and hypermotility significantly at $10 \mathrm{mg} / \mathrm{kg}$, p.o. in reserpinized female rats. The minimal effective doses of terguride and bromocriptine for PRL lowering were 0.03 and $1.0 \mathrm{mg} / \mathrm{kg}$, p.o., respectively, in reserpinized female rats. Thus, terguride at 100 times higher dose than the PRL-lowering dose did not induce stereotypy and hypermotility, whereas bromocriptine induced both stereotypy and hypermotility at 10 times higher dose than the PRL-lowering dose in rats. These findings, together with the results on the emetic action, suggest that the neurotropic side effects of tergu- 
ride are weaker than those of bromocriptine.

The above-mentioned weak effects of terguride on the central nervous system may be due to its partial agonistic action on the postsynaptic $\mathrm{D}_{2}$-receptors in the mesolimbic, nigrostriatal and hypothalamic dopaminergic neurons in the brain, as previously reported $(7,9)$. In the pituitary, like $D_{2}$-agonists, terguride suppresses the PRL secretion in normoprolactinemic male humans (11) and animals (Fig. 7) as well as patients with hyperprolactinemia (12) and animals (Fig. 1). However, it has been reported that terguride, like the partial $D_{2}$-agonist (-)-3-PPP, did not suppress the PRL secretion in normoprolactinemic female rats $(29,30)$, suggesting that terguride may act as a partial agonist at the lactotrophic $\mathrm{D}_{2}$-receptors in normoprolactinemic female rats. Thus the lactotrophic $\mathrm{D}_{2}$-receptors in hyperprolactinemic patients and animals as well as normoprolactinemic male humans and animals may be sensitized, like striatal $\mathrm{D}_{2}$-receptors in Parkinsonian patients and animals, resulting in the agonistic action of terguride on the lactotrophic $\mathrm{D}_{2}$-receptors. Recently, molecular genetic studies have revealed the existence of two receptor isoforms of dopamine $\mathrm{D}_{2}$-receptors. Both isoforms were abundant in the brain, but only one isoform was found in the pituitary (31). Thus, terguride may act as a agonist at the pituitary $\mathrm{D}_{2}$-receptor isoform, whereas terguride may act as a partial agonist at the other $\mathrm{D}_{2}$-receptor isoform in the brain. As shown in Table 1(A), the difference between the affinities of terguride to pituitary $D_{2}$ - and striatal $D_{2}$-receptors may indicate the localization of the two isoforms. Further studies on terguride will be required to clarify the mechanism for the different actions between the lactotrophic and brain $\mathrm{D}_{2-}$ receptors.

Terguride showed no significant effect on the serum GH and LH level in male dogs at the PRL-lowering doses. These results suggest that terguride may have less effects on $\mathrm{GH}$ and $\mathrm{LH}$ secretion from the pituitary.

In reserpinized rats, oral treatment of terguride was about 30 times more effective and showed a longer duration of action than bromocriptine in lowering serum PRL levels. Furthermore, the dose of terguride required for inhibition of milk production in the mammary glands of lactating rats were also about $10-30$ times lower than that of bromocriptine. The bioavailability of terguride (32) (approx. 30\%) was fivefold higher than that of bromocriptine (33) (approx. 6\%), and the binding affinity of terguride to pituitary $\mathrm{D}_{2}$-receptors was twofold higher than that of bromocirptine (Table 1(A)), which seem to explain partly the higher potency of terguride in rats compared to that of bromocriptine.

In normoprolactinemic dogs, bromocriptine inhibited PRL secretion at almost the same dose as terguride. Also, in the inhibition of lactation, bromocriptine has been reported to be 170 times more effective in dogs than in rats (34). These findings suggest that dogs may be sensitive to bromocriptine. Varying metabolic rate or bioavailability of bromocriptine most likely account for the species difference.

In conclusion, the present results suggest that terguride is a potent inhibitor of PRL secretion with less neurotropic side effects compared to bromocriptine, and thus it is a useful anti-hyperprolactinemic agent for the treatment of galactorrhea and prolactinoma.

\section{Acknowledgments}

The authors wish to thank Dr. Y. Nishino (Schering AG, Berlin, Germany) for his valuable instruction concerning our studies in dogs.

\section{REFERENCES}

1 Chiodini, P.G., Liuzzi, A., Cozzi, R., Verde, G., Oppizzi, G., Dallabonzana, D., Spelta, B., Silvestrini, F., Borghi, G., Luccarelli, G., Rainer, E. and Horowski, R.: Size reduction of macroprolactinomas by bromocriptine or lisuride treatment. J. Clin. Endocrinol. 53, 737-743 (1981)

2 Schmidt-Gollwitzer, M.: Suppression of lactation. In Lisuride and Other Dopamine Agonists, Edited by Calne, D.B., Horowski, R., McDonald, R.J. and Wuttke, W., pp. 301-312, Raven Press, New York (1983)

3 Cuellar, F.G.: Bromocriptine mesylate (Parlodel) in the management of amenorrhea/galactorrhea associated with hyperprolactinemia. Obstet. Gynecol. 55, 278-284 (1980)

4 Friessen, H. and Tolis, G.: Use of bromocriptine in the galactorrhea-amenorrhea syndromes: the Canadian cooperative study. J. Clin. Endocrinol. 6, Supp. $91-99$ (1977)

5 Kletzky, O.A., Marrs, R.P. and Davajan, V.: Management of patients with hyperprolactinemia and normal or abnormal tomograms. Am. J. Obstet. Gynecol. 147, 528-532 (1983)

6 Kehr, W.: Transdihydrolisuride, a partial dopamine receptor antagonist: effects on monoamine metabolism. Eur. J. Pharmacol. 97, 111-119 (1984)

7 Stephens, D.N., Lchmann, P.A., Lanzingewr, C., Wachtel, H., Montogomery, A.M.J. and Herberg, L.J.: Unusual interactions between the neuroleptic haloperidol and the dopamine $\mathrm{D}_{2}$ partial agonist, terguride. Behay. Pharmacol. 1, 521-529 (1990)

8 Wachtel, H. and Dorow, R.: Dual action on central dopamine function of transdihydrolisuride, a 9,10-dihydrogenated analogue of the ergot dopamine agonist lisuride. Life Sci. 32, $421-432$ (1983)

9 Yamaguchi, M., Kimura-Iwasaki, K., Akai, T., Nakada, Y. and Nakagawa, $H$.: Terguride, a dopamine $D_{2}$ partial agonist, as a discriminative stimulus in rats. Behav. Pharmacol. 2, 233- 240 (1991)

10 Wachtel, H., Dorow, R. and Sauer, G.: Novel $8 \alpha$-ergolines with inhibitory and stimulatory effects on prolactin secretion in rats. Life Sci. 35, 1859-1867 (1984)

11 Ciccarelli, E., Touzel, R., Besser, M. and Grossman, A.: Terguride-a new dopamine agonist drug: a comparison of its neuroendocrine and side effect profile with bromocriptine. Fertil. Steril. 49, 589-594 (1988) 
12 Graef, K.-J., Kohler, D., Horowski, R. and Dorow, R.: Rapid regression of macroprolactinomas by the new dopamine partial agonist terguride. Acta Endocrinol. 111, 460-466 (1986)

13 Dall'Ara, A., Lima, L., Cocchi, D., Di Salle, E., Cancio, E., Devesa, J. and Muller, E.E.: Inhibitory effect of cabergoline on the development of estrogen-induced prolactin-secreting adenomas of the pituitary. Eur. J. Pharmacol. 151, 97-102 (1988)

14 El Etreby, M.F., Richter, K.-D. and Gunzel, P.: Histological and histochemical differentiation of the glandular cells of the anterior pituitary in various experimental animals. In Excerpta Medica International Congress Series No. 288, pp. 270-281, Excerpta Medica, Amsterdam (1972)

15 Nicholas, K.R. and Hartmann, P.E.: Progesterone control of the initiation of lactose synthesis in the rat. Aust. J. Biol. Sci. 34, $435-443$ (1981)

16 Costall, B. and Naylor, R.J.: On the mode of action of apomorphine. Eur. J. Pharmacol. 21, 350-361 (1972)

17 Kimura, K., Akai, T., Nakamura, K., Yamaguchi, M., Nakagawa, $H$. and Oshino, N.: Dual activation by lisuride of central serotonin 5- $\mathrm{HT}_{\mathrm{IA}}$ and dopamine $\mathrm{D}_{2}$ receptor sites: drug discrimination and receptor binding studies. Behav. Pharmacol. 2, 105-112 (1991)

18 Lowry, O., Rosebrough, N.J., Farr, A.L. and Randall, R.J.: Protein measurement with the Folin phenol regent. J. Biol. Chem. 193, 265-275 (1951)

19 Rovescalli, A.C., Brunello, N., Monopoli, A., Ongini, E. and Racagni, G.: Absence of $\left[{ }^{3} \mathrm{H}\right] \mathrm{SCH} 23390$ specific binding sites in anterior pituitary: dissociation from effects on prolactin secretion. Eur. J. Pharmacol. 135, 129-136 (1987)

20 Graef, K.-J., Friedreich, E., Matthes, S. and Hassan, S.H.: A homologous radioimmunoassay for canine prolactin and its application in various physiological states. J. Endocrinol. 75, 93-103(1977)

21 Cocola, F., Udeschini, G., Secchi, C., Panerai, A.E., Neri, P. and Muller, E.E.: A rapid radioimmunoassay method of growth hormone in dog plasma. Proc. Soc. Exp. Biol. Med. 151, 140-145 (1976)

22 Boyns, A.R., Jones, G.E., Bell, E.T., Christie, D.W. and Parkes, M.F.: Development of a radioimmunoassay for canine luteinizing hormone. J. Endocrinol. 75, 93-107 (1977)

23 MacLeod, R.M. and Lehmeyer, J.E.: Studies on the mechanism of the dopamine mediated inhibition of prolactin secretion. Endocrinology 94, 1077-1085 (1974)
24 Del Pozo, F. and Fluckiger, E.: Pharmacological aspects of the prolactin inhibitor bromocriptine. In Clinical Neuroendocrinology: A Pathophysiological Approach, Edited by Tolis, G., pp. 429-435, Raven Press, New York (1979)

25 Caron, M.L., Beaulieu, M., Raymond, V., Gagne, B., Drouin, J., Lefkowitz, R.J. and Labrie, F.: Dopaminergic receptors in the anterior pituitary gland. J. Biol. Chem. 253, 2244-2253 (1978)

26 Enjalbere, A. and Bockaert, J.: Pharmacological characterization of the $D_{2}$ dopamine receptor negatively coupled with adenylate cyclase in rat anterior pituitary. Mol. Pharmacol. 23, $576-584$ (1983)

27 Di Paolo, T. and Falardeau, P.: Dopamine receptors in rat pituitary and estradiol-induced pituitary tumor; effect of chronic treatment with bromocriptine. Biochem. Biophys. Res. Commun. 123, 312-316 (1984)

28 Vrontakis, M.E., Thiveris, J.A. and Friesen, H.G.: Influence of bromocriptine and oestrogen on prolactin synthesis, secretion and tumor growth in vivo in rats. J. Endocrinol. 113, 383-388 (1987)

29 Carlsson, M., Carlsson, A. and Eriksson, E.: The intrinsic activities of the partial dopamine receptor agonists (-)-3-PPP and TDHL on pituitary dopamine receptors are lower in female than in male rats. Eur. J. Pharmacol. 142, 39-43 (1987)

30 Carlsson, M. and Eriksson, E.: The intrinsic activity of (-)-3PPP (Preclamol) on pituitary DA receptors in female rat is enhanced following chronic DA depletion. Life Sci. 42, 585-588 (1988)

31 Giros, B., Sokoloff, P., Martres, M.-P., Riou, J.-F., Emorine, L.J. and Schwartz, J.-C.: Alternative splicing directs the expression of two $D_{2}$ dopamine receptor isoforms. Nature 342, $21-28$ (1989)

32 Washio, K., Nakashima, H., Yanase, R. and Azuma, H.: Pharmacokinetic studies of terguride (1). Absorption, distribution and excretion in rats. Xenobiotic Metabolism and Disposition (in press) (Abs. in English).

33 Schran, H.F., Tse, F.L.S. and Bhuta, S.I.: Pharmacokinetics and phramacodynamics of bromocriptine in the rat. Biopharm. Drug Dispos. 6, 301-311 (1985)

34 Martin, P. and Bateson, P.: The lactation-blocking drug bromocriptine and its application to studies of weaning and behavioral development. Dev. Psychobiol. 15, 139-157 (1982) 